\title{
Reflecții catehetice pentru pastorația persoanelor îndoliate
}

\author{
Vasile CREȚ*
}

Abstract: Catecheical reflections for the pastoral care of greiving
persons. The context of today's world reveals a society overwhelmed
with self-esteem, seasoned with the successful goals of the daily agenda,
hurried to consume indiscriminately, greedy for any smell, taste and
thought that provokes pleasure. In the face of the spectacle that unfolds
uninterruptedly before our eyes, on television, at work and in traffic, the
contemporary man is rather accustomed to the death of others, in
accidents and crimes presented in the news. Time flies irreversibly, and
if we ask people what they think about the passing of time, most will say that it is slipping away. Therefore, we live on the run, we eat on the run, we love on the run, we sleep on the run. We live in a world where action and feverishness are valued. The watchwords seem to be activity, movement, success. We have entered a civilization that hates pause, suspension, inactivity. Thinking of the future, we must wisely govern every day of our lives. In other words, the time we have at our disposal can be the time of falling or the time of rising, it can be the time of fruiting or the time of scattering the gifts we have been endowed with by God. When man thinks of his death, then he begins to despise the vanity of the world. His pleasures and pains appear to him, at the same time, laden with futility, and then a little miracle happens in his soul: there is silence. Extracted from the noise, the priorities, the activities that consume his soul, the man takes the relentless reality of death and lays it like a tombstone over what almost everyone calls life. The liturgy of death is a true Christian pedagogy of love, attachment and respect between members of the same family (children towards their deceased parents and siblings, but also parents towards their own deceased children) and between members of the Church, the great Christian family. In other words, what we do for our parents and relatives past to

* Preot, Conf. univ. la Facultatea de Teologie Ortodoxă „Justinian Patriarhul” a Universității București. 
eternity must be repeated by our with us. This is the proof of love that does not forget those who are no longer among us and who is stronger than death, passing beyond the entrance of the grave.

Keywords: death, grief, funeral, catechesis, pastoral care

\section{Absurdul morții într-o lume hedonistă}

Contextul lumii de astăzi ne dezvăluie o societate copleșită de stimă de sine, asezonată cu obiectivele reuşite ale agendei zilnice, grăbită să consume fără discernământ, pofticioasă la orice miros, gust și gând ce îi provoacă plăcere. În societatea de consum în care trăim, imperativul este satisfacerea imediată a dorințelor individuale. Când pe multe ecrane se pot vedea reclame înfățișând chipuri strălucind de tinerețe și de sănătate, moartea, ca realitate de netăgăduit, este un subiect tabu și, prin urmare, ar putea fi considerată o impudoare. Trupuri goale și sentimente intime sunt afișate în piaţa publică, în timp ce un trup lipsit de viaţă devine stânjenitor și trebuie să ne debarasăm de el cât mai repede cu putință, ascuzându-l sub pământ sau incinerându-l, pentru a nu ne mai chinui amintirile. Preotul John Breck, în prefața unei cărți, constată că ,,acuta secularizare a societății apusene i-a făcut pe mulți, și chiar pe credincioși, să evite cu orice preț suferința și să nu accepte moartea ca realitate" .

Logica de a seduce şi de a fascina a cosumerismului, prin plăcere şi divertisment, denaturează adevărul revelat prin privatizarea acestuia în opţiuni particulare, transformând comuniunea în existenţă egoistă şi izolată. Totul se structurează prin modul de a fi bazat pe plăcere, prin eludarea Crucii care duce la Înviere:

„Societatea actuală se prezintă ca fiind civilizaţia dorinţei
care consacră un adevărat cult dedicat bunăstării materiale şi
plăcerilor imediate. Plăcerile consumului se exhibă peste tot,
imnurile aduse timpului liber şi vacanţelor răsună
pretutindeni, totul se vinde ca promisiune a fericirii
individuale. A trăi mai bine, «a profita de viaţă», a te bucura

1 Antonie de Surou, Viața, Boala, Moartea, trad. Anastasia Igiroșanu, SlatinaNera, Edit. „Sfântul Siluan”, 2010, p. 12. 
de confort şi de noutăţile din comerţ, apar ca nişte drepturi ale individului, nişte scopuri în sine, nişte preocupări zilnice în proporţii de masă. Se desfăşoară o întreagă cultură care te invită să guşti din plăcerile clipei, să profiţi de fericire aici şi acum, să trăieşti numai pentru tine; ea nu mai prescrie renunţarea, ea face să strălucească literele de foc ale noii Evanghelii: "Cumpără, bucură-te, aceasta e legea şi aceştia sunt profeţii!». Aceasta e societatea de consum a cărei ambiţie afişată este de a elibera principiul plăcerii, de a smulge omul dintr-un întreg trecut de privaţiuni, de inhibiţie şi de ascetism. Gata cu poruncile disciplinare şi rigoriste, este momentul clamării dorinţelor materiale, al celebrării divertismentului şi consumului, al desfătării perpetue în plăceri private" 2 .

În fața spectacolului ce se desfășoară neîntrerupt în fața ochilor, la televizor, la serviciu și în trafic, omul contemporan este obişnuit mai degrabă cu moartea celorlați, în accidente și în crime prezentate la știri. Tresare, totuși, la trecerea din viața aceasta a persoanelor foarte apropiate, cu care a intrat în contact, precum și a celor din familia sa. Simţim, probabil în subconştient că, venind în contact cu moartea, sub orice formă, ne confruntăm oarecum cu perspectiva propriei noastre morţi, ce ne devine astfel mai aproape, mai reală, mai certă. Nu se poate ca trupul neînsufleţit al cuiva să nu ne smulgă, măcar în treacăt, un gând la efemeritatea vieţii şi să nu ne ducă fulgerător în preajma momentului propriei noastre morţi. Într-un fel anume, fiecare şi-a zis, măcar o dată în viaţă: ,şi mie mi se va întâmpla aceasta".

\section{Timpul vieții noastre: aliat prețios sau inamic nemilos?}

Timpul fuge ireversibil şi, dacă îi întrebăm pe oameni ce gândesc despre trecerea zilelor, cei mai mulţi vor spune că ele ne scapă ca printre degete. Aşa se face că trăim pe fugă, mâncăm pe

2 Gilles LiPOVETSKY, Fericirea paradoxală. Eseu asupra societătii de hiperconsum, Iași, Edit. Polirom, 2007, p. 86. 
fugă, iubim pe fugă, dormim pe fugă. Fast food, shortcut, coffee to go, totul e viteză, toate se fac pe repede-înainte în ritm ameţitor. $\mathrm{Nu}$ ajungem bine într-un loc şi deja ne gândim la cum arată următorul popas. Intre dimineaţă şi seară e sprintul. Ne trezim că trec anotimpurile peste noi. Anii, fug şi ei. Mulţi dintre noi ne ducem viaţa în birouri rigide, în zgomotul tastelor şi al aparatelor de aer condiţionat, închişi în faţa calculatoarelor, despre care ne amăgim că ar fi ferestre spre lume. Visăm pe google, râdem pe facebook, ne dăm întâlnire pe zoom. Avem electrocasnice pentru toate activităţile cotidiene dintr-un cămin. Avem lifturi care ne urcă mai repede etajele. Toate sunt menite să ne uşureze viaţa, să ne ofere secunde preţioase. Şi, cu toate acestea, avem tot mai puțin timp. „,N-am timp" este, de departe, şlagărul vremurilor noastre şi boala oamenilor moderni. $\mathrm{N}$-avem timp de zâmbit sau de sperat, n-avem timp de clădit caractere sau de şlefuit personalităţi, n-avem timp şi resurse de educat copiii şi tinerii, n-avem timp să mai citim o carte sau să ne plimbăm în parc. Îi sunăm pe cei dragi în grabă, poate din automatism, ca apoi să-i repezim, spunându-le ,n-am timp!”. Avem timp doar cât să ne plângem că n-avem timp.

Trăim într-o lume în care sunt valorizate acţiunea şi febrilitatea. Cuvintele de ordine par a fi activitate, mişcare, reuşită. Am intrat într-o civilizaţie care repudiază pauza, suspendarea, inactivitatea. Căci, nu-i aşa?, timpul înseamnă bani, uneori chiar putere. Omul contemporan e un malaxor al orelor care se succed, anost, din secundă în minut, dinspre casă spre serviciu și apoi, vlăguit, înapoi spre casă. În iureşul nebunesc al vieţii de azi, n-ar fi rău să recuperăm obiceiul de a „opri în loc” timpul, adică de a ieşi, din când în când, din goana lui. Nu pledez, fireşte, pentru trândăvie. Pledez pentru refuzul lăcomiei de a „folosi” fiecare clipă, de a trăi într-o nesănătoasă foame de timp, abandonând răgazurile, contemplativitatea şi nemişcarea. Goetheanul „Opreşte-te, clipă!” asta înseamnă: transformă timpul care curge în timp care stă, în timp care îţi lasă libertatea de a te întâlni cu tine însuţi şi cu Dumnezeu. Pentru că Îl căutăm pe Dumnezeu în timp ce ne căutăm pe noi înșine, căutarea de sine devine cea mai înaltă realizare a existenței noastre. 
Atunci când ne sărbătorim ziua de naștere, constatăm că un an în plus este, de fapt, un an în minus. De asemenea, ne dăm seama că azi eşti mai bătrân decât ai fost vreodată, şi totuşi eşti mai tânăr decât vei fi de acum înainte. Moartea este atât de sigură de „victoria" ei, încât ne dă un avans de o viaţă întreagă. De fiecare dată când adormim, la căderea nopţii, pregustăm din moarte şi de fiecare dată când ne trezim, în dimineaţa următoare, suntem de parcă am fi înviat din morţi. Sfârşitul unei clipe, al unei ore, al unei zile, al unei săptămâni, al unei luni, finalul unui an, toate acestea ne duc cu gândul la sfârşitul nostru pământesc, la necesitatea de a ne pregăti drumul spre veşnicia lui Dumnezeu, care nu cunoaște limite temporale: „Că o mie de ani înaintea ochilor Tăi sunt ca ziua de ieri, care a trecut şi ca straja nopţii" (Ps. 89, 4).

Este important să înţelegem că, plecându-ne genunchii la rugăciune, seara şi dimineața, ne eliberăm de grijile şi gândurile noastre lumeşti. Din această reflecţie se pot naşte cel puţin două gânduri. Primul trimite la vremelnicia vieţii noastre, privind la anii care au trecut, amintindu-ne de persoanele dragi pe care le-am pierdut sau de care ne-am despărţit, uitându-ne la obiectele din jurul nostru pe care nu le mai folosim: „Anii noştri s-au socotit ca pânza unui păianjen; zilele anilor noştri sunt şaptezeci de ani. Iar de vor fi în putere optzeci de ani şi ce este mai mult decât aceştia osteneală şi durere. Că trece viaţa noastră şi ne vom duce” (Ps. 89, 10-12). Al doilea gând exprimă setea omului după viaţa veşnică, despre care ne aduce aminte şi Fericitul Augustin atunci când spune: „m-ai creat pentru tine, Doamne, şi nefericit este sufletul meu până ce nu se va odihni întru Tine"3. Chiar dacă am trăi douăzeci, cincizeci sau o sută de ani, ne-am da seama că toate lucrurile care ne înconjoară sunt limitate şi trecătoare şi că noi avem în suflet o sete nesfârşită după viaţa veşnică, după întâlnirea cu Dumnezeu, izvorul vieţii şi al nemuririi.

Cugetând la cele viitoare, trebuie să chivernisim cu înţelepciune fiecare zi din viaţa noastră, ca să nu ni se aplice şi

${ }^{3}$ SFÂntul Augustin, Confesiuni, ediție bilingvă, trad., introd. și note de Eugen Munteanu, București, Edit. Humanitas, 2018, p. 205. 
nouă cuvintele pe care proorocul David le zicea iudeilor: „Şi s-au stins în deşertăciune zilele lor şi anii lor degrabă" $(P s .77,37) . \mathrm{Cu}$ alte cuvinte, timpul pe care îl avem la dispoziţie poate fi timpul căderii sau timpul ridicării, poate fi timpul rodirii sau timpul risipirii darurilor cu care am fost înzestrați de Dumnezeu: „Invaţăne să socotim bine zilele noastre, ca să ne îndreptăm inimile spre înţelepciune" (Ps. 89, 14). Totul depinde de noi, de credința, voința şi lucrarea noastră, dacă sfinţim timpul prin rugăciune, pocăință și fapte bune sau irosim timpul vieții noastre prin nepăsare, lenevire și amânare.

\section{Timpul liturgic deschide pe om spre veşnicia lui Dumnezeu}

Din timpuri străvechi şi până astăzi, filosofii, gânditorii şi teologii deopotrivă, au fost preocupaţi de timp şi de concepţia despre timp, încercând să răspundă întrebărilor precum: de unde a apărut, care este esenţa lui, care este scopul şi valoarea sa, ce legătura există între timp, lume şi om.

Sfânta Scriptură relatează că lumea a fost creată de Dumnezeu din nimic: „La început, Dumnezeu a făcut cerul şi pământul" (Fc. 1,1), acest început fiind înţeles şi ca început al creaţiei, dar şi al timpului. Este momentul ,zero" în care necreatul devine creat, ceea ce nu este începe să existe, purtând în sine amprenta timpului cu toate consecinţele sale: mişcare, devenire, schimbare, moarte. De aici, înţelegem că tot ceea ce este creat are un început şi, implicit, un sfârşit. Întru acest început al creaţiei, voinţa divină se manifestă şi devine lucrătoare în timp, astfel că „timpul este o formă a existenţei create, în vreme ce veşnicia aparţine în mod propriu lui Dumnezeu"4.

În ce priveşte esenţa lui, nu ştim ce este timpul, însă ştim cum se manifestă şi îi recunoaştem amprenta pe care o pune el în creaţie: prin durată, schimbare, devenire, trecerea de la o stare la

4 Daniel CıовотеA, „Timpul şi valoarea lui pentru mântuire în Ortodoxie”, în Ortodoxia, 2/1977, p. 196. 
alta, putând fi caracterizat ca având în sine mişcarea, deşi nu se confundă cu ea. Prin urmare, „timpul este modul de existenţă al creaturii, iar veşnicia, modul de existenţă al lui Dumnezeu"5, două moduri de existenţă distincte, dar nu opuse.

Biblia menţionează trei termeni ai temporalităţii: cronos, kairos şi eon. Dacă primii doi se referă la viaţa lumii şi la modul ei de existenţă, experiată de creatură, eonul are în vedere viaţa veşnică, eternitatea proprie lui Dumnezeu. În gândirea biblică, kairos şi cronos sunt complementari ${ }^{6}$.

Cronosul este timpul uman, măsurabil din punct de vedere fizic, marcat de nestatornicia firii umane, de neputinţa lui de a se ridica, plin de căderi şi ridicări. Pentru om, cronosul este preludiul morţii, clipa, luna, anul fiind măsura morţii progresive. Dacă timpul este legat de materie, sufletul nemuritor nu este supus naşterii şi morţii, el putând să devină prin mişcare, înălţat sau decăzut după cum ştie să folosească timpul ce i s-a dat de Dumnezeu. Timpul cronologic nu se poate repeta, ceea ce denotă o linie dreaptă irepetabilă. Prezentul este oglinda veşniciei pentru că nu are durată, nu poate fi cuantificat ${ }^{7}$. Sfânta Scriptură afirmă iminenţa unui sfârşit al cronologiei cosmice universale. Hristos, Cuvântul divin, este Cel ce arată contrastul între Adevărul veşnic al lui Dumnezeu şi cronologia universală prin cuvintele „Cerul şi pământul vor trece, dar cuvintele Mele nu vor trece" (Mt. 24, 35).

Kairosul este timpul nemăsurabil, umanizat şi spiritual, în care Dumnezeu lucrează în sfinţii Lui $(P s .67,36)$ şi realizează în oameni zidirea Trupului Fiului Său. Kairosul este timpul raportat la veşnicie, deschis experienţei atemporale şi supratemporale. Prin el, viaţa umană accede la viitor şi la trecut, pătrunde prin iubire în toată creaţia, uneşte în rugăciune viii şi morţii şi luminează istoria trecută, prezentă şi viitoare. Kairos este timpul unirii omului cu Dumnezeu, căci el reprezintă pătrunderea luminii necreate în creaţie

5 Ibidem, p. 197.

6 Ioan Valentin IsTRATI, Taina veacurilor. Unirea timpului cu eternitatea în rugăciunile Bisericii, Iași, Edit. Doxologia, 2010, p. 89.

${ }^{7}$ Ibidem, p. 90. 
şi răspunsul omului la chemarea lui Dumnezeu. El devine subiectiv omului în perspectiva mântuirii. Nu există, de aceea, un moment de început sau sfârşit al kairos-ului în viaţa omului credincios. Omul se uneşte cu Dumnezeu în dialog prin ritmul de viaţă al slujbelor liturgice ale Bisericii ${ }^{8}$.

Eonul este folosit mai ales pentru a indica timpul ca durată şi exprimă atât timpul acestei lumi - „Veacurile s-au întemeiat prin cuvântul lui Dumnezeu" (Evr. 11, 3), cât şi veşnicia lui Dumnezeu $(R m .16,26)$. Sfânta Scriptură defineşte eonul ca fiind timpul nelimitat sau veşnicia dumnezeiască. Totuşi, veşnicia nu desfiinţează timpul, ci coexistă cu el. Dacă s-ar considera că cele două realităţi sunt antagonice, legătura între Dumnezeul Cel veşnic Viu şi omul vremelnic s-ar destrăma, fără doar şi poate, iar dialogul dintre Dumnezeu şi om ar fi imposibil ${ }^{9}$. Omului îi este dat să participe la infinitate prin har; în infinitate nu există timp, iar dorul după această infinitate susţine mişcarea noastră în ordinea finită ${ }^{10}$. Hristos este unirea Dumnezeirii cu umanitatea, a veşniciei ipostatice cu timpul uman şi a nemărginirii ontice cu spaţiul limitat al firii umane. După cădere, omul a conştientizat faptul că menirea sa nu era aceea de a muri în timp, ci de a înveşnici timpul prin întoarcerea sa cu faţa spre Creatorul său. Hristos afirmă în Evanghelia Sa că ,vine ceasul şi acum este” sau ,vine ceasul şi a şi venit”, ceea ce înseamnă că prin El, timpul a căpătat deja amprenta veşniciei încă din această viaţă pământească. Iar acest lucru îl poate realiza tot omul care crede Cuvântului celui Viu şi se întoarce la Dumnezeu prin pocăinţă şi credinţă.

Prin urmare, timpul nu este doar unitatea cu care se măsoară mişcarea şi devenirea, ci însuşi cadrul în care se desfăşoară viaţa şi urcuşul duhovnicesc, iar de întrebuinţarea pe care i-o dăm noi înşine depinde, pentru viitor şi pentru veşnicie, starea bună sau rea a fiecăruia. Timpul nu se măsoară numai cu anii, ci mai ales cu

\footnotetext{
${ }^{8}$ Ibidem, p. 92.

${ }^{9}$ Ibidem, p. 93.

10 Dumitru Stănilone, Teologia Dogmatică Ortodoxă, vol. I, Bucureşti, Edit. Institutului Biblic și de Misiune al Bisericii Ortodoxe Române, 2010, p. 168.
} 
roadele. Este important ca omul să dorească nu numai să trăiască mult, ci să trăiască frumos, cu sens, să vieţuiască creştineşte. Nu doar să adăugăm la vârsta noastră cât mai mulţi ani trăiţi fără folos, ci să întrebuinţăm cât mai bine şi cât mai înţelept fiecare zi pe care Dumnezeu ne-o dă de trăit. Într-o viaţă de numai câţiva ani, în câteva zile ori chiar în câteva clipe, omul poate dobândi fericirea veşnică sau o poate pierde pentru totdeauna. Pentru cel cu adevărat înţelept, niciun an, niciun anotimp, nicio zi şi nicio clipă nu trebuie lăsate la voia întâmplării, fără rod, asemenea norilor fără de apă, purtaţi din loc în loc de vânturile deşertului.

Dacă în mitologia greacă, timpul era neîndurător, după imaginea zeului Cronos care îşi înghiţea copiii, în religiile antice, timpul era un prilej de suferinţă. Pentru un creştin, timpul vieţii este vremea pentru sfinţire şi mântuire. În acest sens, Sfântul Ioan Hrisostom, spune: „De va pierde cineva aur sau argint, poate va afla în locul lui altul, dar cel ce pierde timpul vieţii sale în nelucrare sau în nerodire, altul nu mai poate afla"11. Astfel, creştinul nu fuge de timp, de trecut sau de istorie, pentru că istoria nu se transformă în neant, ca în vechile religii, sau în curentele sincretiste moderne, ci trecutul, prezentul şi viitorul se vor transforma în Eshaton, adică în Împărăţia lui Dumnezeu, în bucurie veşnică sau în tristeţe veşnică. Orice om ar trebui să privească cu încredere, cu optimism, dar şi cu gravitate fiecare clipă a vieţii sale, gândindu-se că fiecare secundă este o şansă pentru ridicare, pentru iertare, dar şi pentru rodire.

\section{Perspectiva creștină asupra morții}

Pentru cei mai mulți oameni, moartea pare absurdă. Adâncurile sufletului nostru nu concep nefiinţa şi nici stări temporare de desfacere a sufletului de trup, omul fiind ,icoana” divinităţii în lumea materială. Pentru a înţelege cum a apărut moartea, va trebui să înţelegem starea omului dinainte şi după

${ }^{11}$ SFÂNTUl IOAN GURĂ DE AUR, Omilii la parabola despre săracul Lazăr și bogatul nemilostiv, trad. Adrian Tănăsescu-Vlas, București, Edit. Sophia, 2002, p. 16. 
căderea în păcat. Iniţial, alcătuirea trup-suflet era nemuritoare, fiind susţinută prin comuniunea omului cu Dumnezeu. Căderea în păcat a fost o încercare a omului de a ajunge ca Dumnezeu, nu ,asemenea" Lui, prin sine însuşi. În acel moment, comuniunea dintre om şi Dumnezeu a fost alterată, ceea ce a dus şi la alterarea felului în care omul exista.

Ca exemplificare, să ne imaginăm un tată şi un copil care îşi propun să parcurgă un drum greu pentru copil, dar uşor pentru tată. Câtă vreme tatăl îl sprijină pe copil, iar copilul rămâne lângă tatăl său, greutăţile drumului sunt aproape inexistente, puterea tatălui sprijinind şi copilul. Dar ce se întâmplă când copilul, părăsindu-şi tatăl, crede că poate parcurge singur drumul? Evident, greutăţile îl vor copleşi şi îi vor îngreuia deplasarea, fiind posibilă chiar şi dispariţia sa totală pe drum. Cam aşa a făcut şi omul faţă de Dumnezeu. „Pomul cunoştinţei binelui şi răului" era, de fapt, simbolul inutilităţii separaţiei de „binele” divin, ceea ce aducea „cunoaşterea răului” (în fapt, părăsirea comuniunii era o practicare a răului, termenul biblic „cunoaştere” referindu-se la experiere, trăire, însoţirea cu ceva, nicidecum doar la o cunoaştere ideologică).

Consecinţa practicării răului a fost pierderea nemuririi, alterarea firii materiale, ,îngreunarea" ei cu boli şi moarte trupească. Firea umană nu şi-a mai luat energia existenţială din comuniunea cu Dumnezeu, ci din ea însăşi, ceea ce, la un moment dat, duce la epuizarea acestei energii, la sfârşitul biologic. Dar şi acest lucru este tot spre binele omului, căci pomul respectiv avusese rolul de jalon. Când a depăşit norma morală, pomul şi-a îndeplinit acest rol, precizat dinainte de Dumnezeu, spre a nu se perpetua răul la nesfârşit: „Omul din ziua de azi, cu inima lui coruptă, este tentat să întrebe de ce Dumnezeu, dacă a creat pe om nemuritor, hărăzit fericirii eterne, i-a pus totuşi în față pomul cunoașterii binelui și răului, din care i-a interzis să mănânce. De ce i-a pus deci ispita în față, El, Atotştiutorul, cunoscând că omul va cădea, ispitit de cel rău? Acest pom al ispitei i-a fost pus omului în cale tocmai pentru ca el să-și dea permanent seama că este o ființă creată, supusă 
Creatorului Său, și nu egală cu El, Căruia îi datorează fericirea nemuritoare, dar și ascultare și supunere" 12 .

Părintele Dumitru Stăniloae afirmă că

„spaima de moarte arată că ea nu e un fenomen cu totul natural, ci că s-a produs ca un fenomen contrar naturii, ca o slăbire a comuniunii cu Dumnezeu, izvorul vieţii. Creştinismul explică această spaimă de moarte prin faptul că ea a apărut ca pedeapsă şi ca urmare a păcatului primilor oameni, pentru ieşirea lor din comuniunea cu Dumnezeu. De aceea creştinul manifestă deschis şi o teamă de durerile morţii ca despărţire a sufletului de trup, cum a manifestat şi Hristos, recunoscând astfel acest caracter nenatural al morţii, spre deosebire de cei care, pe de o parte, declară moartea un fenomen natural, iar pe de altă parte, au o spaimă disperată de moarte, cu mult mai mare decât creştinii. Dar creştinismul oferă şi un remediu al spaimei de moarte întrucât moartea în Hristos este un mijloc de ridicare a noastră din viaţa nedeplină şi trecătoare în care ne-am coborât, la viaţa fără de moarte, la plenitudinea vieţii prin întâlnirea cu Hristos dincolo de moarte, după ce am trăit în parte cu El aici. Iar siguranţa întâlnirii cu El, a depăşirii morţii noastre, o avem în biruinţa morţii de către El prin Înviere" ${ }^{13}$.

Dictonul cunoscut al filozofiei antice, memento mori (,nu uita că vei muri”), și-a găsit un puternic susținător în teologia patristică. Spre deosebire de conceptul filozofic însă gândirea creștină a înfrumusețat această piatră de hotar a existenței noastre, unind-o cu începutul vieții veșnice. Pornind meditația sa referitoare la ceasul de pe urmă al existenței lumești și, totodată, cel de început al vieții veșnice, Evagrie Ponticul se referă exact la această așezare a morții în spațiul care i se cuvine, deși omul refuză să-i consacre fie și cel mai mic gând al vieții lui. „Aşezându-te în chilia ta, adună-ţi mintea şi gândeşte-te la ceasul

${ }^{12}$ Paulin LeCA, Ce este moartea?, Bucureşti, Edit. Lumea Credinţei, 2009, p. 34.

${ }^{13}$ Dumitru Stăniloae, Teologia Dogmatică..., vol. III, p. 232. 
morţii. Priveşte atunci la moartea trupului, înţelege întâmplarea, ia-ţi osteneala şi dispreţuieşte deşertăciunea din lumea aceasta, atât a plăcerii, cât şi a străduinţei, ca să poţi să rămâi nestrămutat în aceeaşi hotărâre a liniştii şi să nu slăbeşti”"14.

Când omul se gândește la moartea sa, atunci începe să disprețuiască deșertăciunea lumii. Plăcerile și durerile sale îi apar, deopotrivă, încărcate de zădărnicie și, atunci, în sufletul său se petrece o mică minune: se aşterne liniştea. Extras din mijlocul zgomotului, al priorităților, al activităților ce îi consumă sufletul, omul ia realitatea implacabilă a morții și o așterne asemenea unei pietre de mormânt peste ceea ce aproape toți numesc viață. Acum este momentul în care începe să înțeleagă că viața lui nu este aici, că adevărata lui existență, viața cea de veci, se apropie, dar că încă nu a gustat din ea, fiind preocupat de alte griji, îndoieli şi neputințe. Gândul la moarte aduce liniște și pace, aduce în vedere ceea ce este cu adevărat important.

Leacul gândului la moarte constă în izbăvirea minții omului de gândurile rele. Cel care meditează la această taină a despărțirii sale de trup, la deșertăciunea lumii, a plăcerii și a durerii care o însoțesc, la pedepsele și răsplătirile vieții de veci și la Judecata cea înfricoșătoare de la sfârșitul veacurilor, nu mai are de ce să strecoare în gândirea sa tot felul de imaginații nepotrivite sau să urmeze ispitele şi gândurile demonice. În faţa morţii aproapelui sau a propriei noastre morţi, oricât de realişti am fi, sentimentele de dezolare, oroare şi chiar indignare sunt justificate. Iisus însuşi a plâns la mormântul prietenului Său, Lazăr (In. 26, 38), iar în grădina Ghetsimani a fost cuprins de frică în faţa imanenţei propriei Sale morţi $(M t$. 26, 38). Sfântul Apostol Pavel consideră moartea ,vrăjmaşul cel din urmă, care va fi nimicit” (1 Cor. 15, 26) şi o leagă strâns de păcat: „,boldul morţii este păcatul" (1 Cor. 15, 56). Moartea este un mijloc de împiedicare a răspândirii răului pe pământ. Dumnezeu, spre binele omului, a trimis moartea în trupul păcătos al acestuia,

14 Evagrie Ponticul, „Schiță monahicească, în care se arată cum trebuie să ne nevoim și să ne liniștim", în Filocalia, vol I, trad. Dumitru Stăniloae, București, Edit. Humanitas, București, 2005, p. 49. 
pentru ca răutatea să nu fie fără de sfârşit, sufletul rămânând în continuare veşnic viu.

Din perspectivă creştină, moartea nu este un sfârşit, ci doar o trecere spre un nou început, autentic şi veşnic. De aceea, nu moartea în sine contează pentru un creştin, ci starea interioară a omului pus în faţa acestei dramatice treceri, stare care se propagă şi se amplifică în veşnicie. Teologul ortodox Kallistos Ware spune că este bine să reţinem trei lucruri în legătură cu locul morţii în viaţa noastră şi atitudinea pe care trebuie să o avem faţă de ea. „Mai întâi, moartea este mai aproape decât ne imaginăm noi. Apoi, ea este profund nenaturală, potrivnică planului dumnezeiesc, dar, în acelaşi timp, şi un dar al lui Dumnezeu. Şi, în sfârşit, este o despărţire care nu este despărţire" ${ }^{15}$. Acelaşi teolog afirmă că, „deşi tragică, moartea este şi o binecuvântare. Cu toate că n-a făcut parte din planul dumnezeiesc, nu este mai puţin un dar al lui Dumnezeu, fiind o expresie a milostivirii şi compătimirii Sale. Pentru noi oamenii, viaţa veşnică în această lume căzută, captivi pentru totdeauna cercului vicios al urâtului şi păcatului, ar fi fost un destin teribil şi insuportabil. Din această cauză, Dumnezeu ne-a oferit o scăpare, desfăcând unirea dintre suflet şi trup pentru a le recrea, a le reuni la învierea cea de obşte şi a le readuce astfel la plenitudinea vieţii" 16 .

Tot ceea ce trăim, toate faptele noastre înscrise în timp ne marchează viaţa, unele mai mult, altele mai puţin, dar ele rămân ca nişte jaloane prin care parcursul nostru poate fi reconstituit şi care ne caracterizează existenţa ca momente decisive. În acest sens, Sfântul Isaac Sirul ne spune că

„viaţa noastră pe pământ este ca o carte pe care o scriem noi, fiecare, prin faptele noastre, prin cuvintele noastre şi prin gândurile noastre. Cât suntem încă în viaţa aceasta putem reveni asupra a ceea ce am scris cu fapta, cu vorba sau cu gândul. Prin pocăinţă, prin îndreptare, prin începutul bun,

15 Kallistos WARE, Impărăţia lăuntrică, trad. Eugenia Vlad, Bucureşti, Edit. Christiana, 1996, p. 25.

${ }^{16}$ Ibidem, p. 27. 
corectăm capitole din viaţa noastră, fraze întregi din cartea vieţii noastre, exprimări greşite! Dar, atunci când s-a încheiat viaţa noastră pe pământ se pune sigiliu pe cartea vieţii noastre şi nu mai putem îndrepta nici capitolele, nici frazele, nici cuvintele, ci rămân aşa cum ne-a găsit ceasul morţii şi ziua judecăţii”' ${ }^{17}$.

Natura înconjurătoare este un proces continuu al învierii. Bobul de grâu nu răsare și nu aduce roadă dacă nu este sădit în pământ, dacă nu moare. Mântuitorul Iisus Hristos a biruit moartea la fiica lui Iair, la tânărul din Nain, la prietenul său, Lazăr, și prin Învierea $\mathrm{Sa}$. Nu se cuvine să deznădăjduiască nimeni dintre cei care cred în Hristos, așa cum spune Sfântul Ioan Gură de Aur: „Nimeni, dar, să nu bocească, nici să plângă, nici să hulească această faptă mare a lui Hristos! Că a biruit moartea! Pentru ce jelești de prisos? Moartea a ajuns somn! Pentru ce te vaieți și plângi? Ar fi de râs chiar dacă păgânii ar face-o! Dar când credinciosul se schimonosește așa, ce apărare mai poate avea? Ce iertare vor avea aceia care se prostesc așa, când de atâta vreme avem dovada clară a învierii?"18.

Moartea este văzută în chip diferit de oameni. Astfel, pentru cei ataşaţi de bunurile pământeşti, ea este un fapt înspăimântător; pentru cei ce o consideră un curs al existenţei, ea apare ca ceva firesc şi o primesc cu resemnare; pentru cei credincioşi, care cred în viaţa viitoare şi o consideră ca ultim scop al vieţii, moartea este primită cu seninătate, fiind socotită o binecuvântare, căci Dumnezeu cunoaște starea fiecărui suflet în parte: „Omul moare atunci când clipa îi este prielnică pentru mântuire, potrivit atotștiinței lui Dumnezeu"19.

Pomenirea morţilor se bazează pe credinţa exprimată în ultimul articol al Crezului: „Aştept învierea morţilor şi viaţa

17 SfÂNtul IsaAc SiRul, Cuvinte despre nevoință, Bacău, Edit. Buna Vestire, 1997, p. 190.

18 SfÂntul IoAn GurĂ DE Aur, Omilii la Matei, col. „Părinți și Scriitori Bisericești”, vol. 23, trad. Dumitru Fecioru, București, Edit. Institutului Biblic şi de Misiune al Bisericii Ortodoxe Române, 1994, p. 385.

19 Jean-Claude LARCHET, Tradiția ortodoxă despre viața de după moarte, trad. Marinela Bojin, București, Edit. Sophia, 2006, p. 25 
veacului ce va să fie". PF Daniel, Patriarhul Bisericii Ortodoxe Române, prezintă câteva argumente în acest sens:

„În primul rând, pomenirea morţilor este un act de credinţă ortodoxă, întrucât ea se bazează pe credinţa că, fiind creat după chipul lui Dumnezeu Cel nemuritor (Fc. 1, 27), sufletul omului este nemuritor (Iov 12,10), chiar dacă trupul omului, după moartea fizică se descompune şi se risipeşte (...). În al doilea rând, pomenirea morţilor este un act de iubire pentru ei. Când ne rugăm pentru cei adormiţi arătăm că îi iubim şi după moarte, iar sufletul lor nemuritor simte iubirea noastră! Iubirea din rugăciunea pentru cei adormiţi este mai tare decât moartea şi ea se arată atât prin cinstirea osemintelor lor, cât şi prin modul în care îngrijim mormintele lor (...). În al treilea rând, actul de pomenire al celor adormiţi în Domnul este un act de speranţă. La Parastasul pentru cei adormiţi întru Domnul, lumânările se aprind pe colivă şi pe colac, pentru că atât coliva cât şi colacul sunt făcute din boabe de grâu, devenite simbol al credinţei în înviere şi al comuniunii frăţeşti în Biserica lui Hristos Cel Înviat (In. 12, 24). După ce s-a terminat slujba Parastasului, coliva şi colacii se împart, se dăruiesc de pomană (spre pomenire) celor prezenţi, mai ales săracilor, iar prin aceasta se săvârşeşte o faptă bună, adică plină de lumină, o faptă a dragostei creştine, care este simbolizată de lumânarea aprinsă deasupra colivei"20.

Ca realitate în sine, există un singur fel de moarte; ca trăire personală, fiecare avem moartea noastră. Simţul de proprietate aruncat asupra vieţii a adus cu sine şi conceptul de ,demnitate” a morţii, ca şi cum omul ar putea să hotărască în locul lui Dumnezeu, ori, cel puţin, împreună cu El, dacă şi în ce măsură să accepte suferinţa înainte de moarte, dacă durerile să-i fie mai mari sau mai mici, ba chiar şi dacă să mai trăiască în condiţii pe care bunul simţ

${ }^{20}$ Daniel, Patriarhul Bisericil ORTOdoXe Române, Iubirea mai tare decât moartea. Inţelesul şi folosul pomenirii morţilor, Bucureşti, Edit. Cuvântul Vieţii, 2012, pp. 7-12. 
comun le numeşte ,nedemne”. Moarte demnă nu poate fi numită, în sens creştin, decât aceea care a fost pregătită de către om deja din viaţă, prin acceptarea locuirii în el a Duhul lui Dumnezeu $(R m .8,9)$ şi prin lucrarea realizată împreună cu El.

\section{Moartea la români, privită cu umor, detașare și superstiţii}

Un mare scriitor român, în debutul unui roman foarte cunoscut, a așezat această frază: „Moartea este un fenomen simplu în natură, numai oamenii îl fac înspăimântător" ${ }^{21}$. Această spaimă a omului față de moarte provine în primul rând din necunoașterea ei, pentru că mulți aleg să evite orice subiect referitor la ea. Cel mai adesea, moartea îl cuprinde pe om nepregătit pentru întâlnirea cu ea, deși este singurul fenomen din univers în privința căruia nu poți avea îndoieli că-l vei rata sau că te va evita.

Unul dintre motivele pentru care se consideră dificil să se discute despre moarte este cel de natură culturală şi se referă la modul în care am fost educaţi cu privire la moarte. Astfel, observăm că, în majoritatea dicţionarelor, termenul de moarte este explicat ca fiind un sentiment ce trece dincolo de experienţa noastră conştientă, pentru că toţi cei care o discutăm nu am trecut niciodată prin ea. Aşa au apărut formele plastice de exprimare a morţii: comparaţiile, analogiile, metaforele şi diversele modalităţi-surogat de transpunere a ei. În orice caz, şirul acestora are o constantă comună, ele întâlnindu-se în ideea că moartea este amorţirea experienţei conştiente pentru totdeauna şi, de aceea, este adesea comparată cu ,somnul” și cu „o călătorie fără întoarcere”.

Noi nu spunem, simplu, despre cineva, că ,a murit”. În limba română, verbul ,a murit" poate fi exprimat într-o varietate foarte bogată de sensuri: filosofic/ateu - ,a trecut în neființă”; astronautic - ,,-a ridicat la cer”; intergalactic - ,s-a dus la stele”; piscicol - ,,s-

21 Marin PREDA, Cel mai iubit dintre pământeni, vol. I, București, Edit. Litera Internaţional, 2009, p. 21. 
a dus pe copcă”; avicol - „a mierlit-o”; legumicol - „,a sfeclit-o”; oftalmologic - ,a închis ochii"; direcțional - „a ieșit cu picioarele înainte”; stradal - „a dat colțul”; cardiologic - „i-a stat inima”; distructiv - ,a crăpat”; ortodox - „1-a luat Dumnezeu”; neortodox „1-a luat dracu"”; pecuniar - ,a dat ortul popii”; spiritualist - „si-a dat duhul"; reciclabil/ ecologic - ,s-a făcut oale și ulcele"; imobiliar - ,și-a luat garsonieră cu ușă-n tavan”; eroic - ,a sucombat"; turistic - „s-a dus într-un loc cu verdeață"; patriotic - ,a închinat steagul"; migraționist - ,a plecat dintre noi”; conjugal „,ne-a părăsit”; topografic - ,,a pornit pe ultimul drum”; poetic - ,i-a apus steaua"; epidemiologic - ,s-a curățat”.

Cât privește taina morții, Dan Puric spune că românul nu are o curiozitate rațională, ci mai degrabă o mirare care dă un sens major vieții și nu mai produce acea frică de necunoscut. E un mod de a te împrieteni cu „destinul” și să faci marea trecere să pară o curgere ${ }^{22}$. „Și de o fi să mor”, spune ciobanul din Miorița, minimalizând tragedia și, cu o înțelepciune duioasă, detensionează învecinarea morții. Românul a văzut tot timpul moartea, a trăit în preajma ei clipă de clipă, și, totuși, pe chip i se citește o decentă împăcare, iar nu groaza. T,ăranul nostru nu este fatalist, ci are o înțelegere fundamentală. Pentru el, moartea, sau cum o numește în înțelesul lui de „trecere dincolo”, se face cu un oarecare regret pământesc, dar și cu o bucurie creștină: „Draga maichii, după tine, îmi pare rău și îmi pare bine!". Acesta este glasul unei mame dintr-un bocet maramureșean. Românul vorbește firesc și creștinesc cu moartea. $\mathrm{Nu}$ avem nimic din patetismul antic al grecilor, din disprețul romanilor, din frica camuflată a omului modern și progresist, nimic din toate acestea. Cuvintele țăranului român, pe care le găsim deseori dăltuite pe crucea de la mormânt, sub forma unui epitaf, sunt pline de înţelesuri: „Învaţă de la viață, că totu-i trecător, să treci frumos prin viață, să poți frumos să mori’. La noi, moartea nu este un dușman al vieții, ci este un partener al ei. Mormântul nu este un loc de blestemat, ci este un loc de îngrijit și de iubit ${ }^{23}$.

${ }^{22}$ Dan Puric, Cine suntem?, București, Edit. Platytera, 2008, p. 42.

${ }^{23}$ Ibidem, p. 43. 
În cunoscutul basm românesc scris de Petre Ispirescu, FătFrumos îi face Tatălui o cerere în plan spiritual absolut: „Tinerețe fără bătrânețe și viață fară de moarte", fără urmă de ispită materială. În viziunea lui Dan Puric, acesta este strigătul unui întreg neam creștin după condiția primară paradisiacă pierdută. Este o îndrăzneală creștină, și nu o obrăznicie, este o cerință acută după calitatea vieții, pentru că esența creștinismului stă în calitatea condiției de Fiu al lui Dumnezeu, și nu în cantitatea biologică, socială sau politică a indiviului în societate ${ }^{24}$. Dar, poate cel mai frumos și concentrat, apropierea și simţirea trecerii dincolo o face nemuritorul nostru poet, Mihai Eminescu, prin versurile poeziei „Nu credeam să învăț a muri vreodată" 25 . Sensul vieții pentru țăranul nostru creștin era Învierea. Sensul vieții pentru omul modern și progresist este longevitatea, uneori prelungită până la absurd. Pentru țăranul nostru, suferința este o poartă către Dumnezeu. Pentru omul modern, suferința este înconjurată de analgezice ${ }^{26}$.

Nimeni nu este stăpânul timpului şi, cu atât mai puţin, al timpurilor. Sfânta Scriptură spune că anii şi vremurile sunt în cârma lui Dumnezeu. Creatorul nostru ne-a adus din nefiinţă la fiinţă şi a hotărât prin planul Său veşnic ca noi să ne naştem într-un anumit spaţiu geografic, din anumiţi părinţi, pentru ca noi să ne împlinim vocaţia pentru care am fost zămisliţi. Nu am venit de nicăieri şi ne îndreptăm spre nicăieri, iar viaţa noastră nu este condiţionată de hazard. Omul secularizat consideră că aproape toate nereuşitele şi eşecurile din viaţă sunt provocate de incompatibilitatea dintre aspiraţiile sale şi caracteristicile zodiei în care s-a născut, iar viaţa lui este modelată de circumstanţe şi de lucruri care i se întâmplă din cauza unor forţe și lucruri exterioare. Însă, data naşterii nu poate predispune pe cineva la a fi virtuos sau pătimaş. Sunt persoane care s-au născut în acelaşi an, în aceeaşi zi, la aceeaşi oră şi au caractere şi înclinaţii cu totul diferite. De ce? Pentru că fiecare om acţionează în virtutea libertăţii pe care a primit-o ca dar nepreţuit de la Dumnezeu.

${ }^{24}$ Ibidem, p. 44.

${ }^{25}$ Mihai EMInESCu, Poezii, București, Edit. Didactică și Pedagogică, 2007, p. 23.

26 D. PURIC, op. cit., 2008, p. 44. 
Pseudoştiinţele care pretind că pot prezice viitorul sunt portiţe pentru a fugi de responsabilitate şi de neputinţele personale. $\mathrm{Nu}$ horoscopul sau mişcarea astrelor pe cer pot influenţa starea de fericire sau nefericire, de fatalism sau eşec, pentru că viaţa fiecărui om se desfăşoară între anumite coordonate care pot fi determinate doar de el însuşi: familie, profesie, prieteni, timp liber, relaţia lui autentică și personală cu Dumnezeu etc. Munca serioasă, perseverenţa, onestitatea, credinţa în Dumnezeu îl pot ajuta să aibă succes în carieră, fericire în familie şi armonie în toate compartimentele vieţii. În baza liberului arbitru de care dispune, fiecare om poate să se autodepăşească în măsura în care îşi înmulţeşte darurile, iar defectele le corectează cu modestie şi migală.

\section{Concluzii}

Cultul morţilor este o veritabilă pedagogie creştină a dragostei, a ataşamentului şi a respectului dintre membrii aceleiaşi familii (a copiilor faţă de părinţii şi fraţii lor răposaţi, dar şi a părinților față de proprii lor copii decedați) şi dintre membrii Bisericii, marea familie creştină. Adică ceea ce facem noi pentru părinţii şi rudeniile noastre trecute la cele veşnice, să facă şi urmaşii cu noi. Aceasta reprezintă dovada dragostei care nu-i uită pe cei ce nu mai sunt printre noi şi care este mai puternică decât moartea, trecând dincolo de pragul mormântului.

„Când cerem lui Dumnezeu «veşnică pomenire» pentru cineva, cerem să fie pomenit de Dumnezeu şi în prezent, cum va fi pomenit în eternitate, deci să-1 ţină neîncetat viu. Dacă am cere ca Dumnezeu să-1 pomenească numai de la judecata din urmă mai departe, ar însemna că Dumnezeu îl ţine uitat pentru o vreme, iar, după aceea, iarăşi îşi va aduce aminte de el. Noi nu cerem lui Dumnezeu să-Şi aducă aminte numai câteodată de acela, ci să-1 aibă neîntrerupt în amintire, în vecii vecilor. Prin rugăciuni, ţinem pe cei ce au fost, veşnic vii. Nimeni nu se pierde definitiv"27.

${ }^{27}$ D. Staniloae, Teologia Dogmatică ..., vol. III, pp. 347. 
Cultul morților trebuie privit și din perspectivă pastoralmisionară, deoarece preotului, cunoscând bucuriile, dar și necazurile păstoriților, nu îi este suficient să rămână la stadiul de cunoaştere, ci trebuie în egală măsură să participe la acestea. La slujba de înmormântare participă și oameni care frecventează biserica mai puțin, în anumite cazuri poate chiar deloc. De aceea, necrologul rostit de preot este deosebit de important. „În viața religioasă a tuturor popoarelor ortodoxe și, îndeosebi, la poporul nostru, cultul morților - adică ansamblul ierurgiilor și al rânduielilor tradiționale prin care Biserica celor vii își arată grija față de cei răposaţi - este foarte dezvoltat, constituind una din manifestările caracteristice și esențiale ale vieții religioase ortodoxe. În afară de scopul lor principal - cel soteriologic - aceste slujbe au și unul catehetic și pedagogic; prin ele, Biserica urmărește adică nu numai să-i ajute pe morți, ci să-i și mângâie pe cei rămaşi în viaţă, să le ușureze durerea, să le amintească nestatornicia lucrurilor pământești și să le întărească speranța și credința în nemurirea sufletului și în învierea morților, dogme de căpetenie ale credinței creștine ortodoxe"28. In plus, nu ştim niciodată când şi cum va fi acel sfârşit, oricare moment poate să fie ultimul şi, ca atare, să se constituie în ultima şansă. De aceea, în fiecare Liturghie, noi cerem „sfârşit creştinesc vieţii noastre” și ,,cealaltă vreme a vieţii noastre în pace şi întru pocăinţă a o săvârși”".

Avem un singur fel de a ne naşte şi milioane de feluri de a muri. Teologic vorbind, viaţa de apoi nu este o destinaţie turistică la care avem acces doar prin moarte. Împărăţia lui Dumnezeu se construieşte de aici. Biserica este agenţia de voiaj a vieţii de dincolo. Moartea este cel mai mare eveniment al vieţii, şi, de aceea, ce este înainte de moarte se răsfrânge asupra a ceea ce este după. Noi avem o întreagă cultură în acest sens: cultul morţilor este legat tocmai de această reciprocitate a lumilor. Altminteri, dacă viaţa ar fi ultima oprire a existenţei, toate ar cădea într-un absurd fără margini. Hristos ne aşteaptă şi pe noi ca să ne limpezească toate întrebările. Important este să avem zbuciumul şi frământarea căutării întâlnirii

${ }^{28}$ Ene BrANişTE, Liturgica Specială, Bucureşti, Edit. Lumea Credinței, 2005, p. 383. 
cu El. Întâlnindu-ne cu El, îl vom auzi spunându-ne: „Adevărat, adevărat zic vouă: Cel ce ascultă cuvântul Meu şi crede în Cel ce M-a trimis, are viaţă veşnică şi la Judecată nu va veni, ci s-a mutat din moarte la viaţă" (In. 5,24).

$\cos \infty$

\section{Bibliografie}

1. Antonie De SuroJ, Viața, Boala, Moartea, trad. de monahia Anastasia Igiroșanu, Slatina-Nera, Edit. „Sfântul Siluan”, 2010.

2. BRANIȘTE, Ene Liturgica Specială, Editura Lumea Credinței, Bucureşti, 2005.

3. СоовотеA, Daniel, „Timpul şi valoarea lui pentru mântuire în Ortodoxie", în Ortodoxia, 2/1977, pp. 196-207.

4. DANIEL, PATRIARHUl BISERICII ORTODOXE ROMÂNE, Iubirea mai tare decât moartea, București, Edit. Cuvântul Vieții, 2012.

5. EmINeScu, Mihai, Poezii, București, Edit. Didactică și Pedagogică, 2007.

6. EVAGRIE PONTICUL, „Schiță monahicească, în care se arată cum trebuie să ne nevoim și să ne liniștim", în Filocalia, vol. I, trad. Dumitru Stăniloae, București, Edit. Humanitas, 2005

7. IsTRATI, Valentin, Taina veacurilor. Unirea timpului cu eternitatea în rugăciunile Bisericii, Iaşi, Edit. Doxologia, 2010.

8. LARCHET, Jean-Claude, Tradiția ortodoxă despre viața de după moarte, trad. Marinela Bojin, București, Edit. Sophia, 2006.

9. LECA, Paulin, Ce este moartea?, Bucureşti, Edit. Lumea Credinţei, 2009.

10. LIPOVETSKY, Gilles, Fericirea paradoxală. Eseu asupra societăţii de hiperconsum, Iași, Edit. Polirom, 2007.

11. PREDA, Marin, Cel mai iubit dintre pământeni, vol. I, București, Edit. Litera International, 2009..

12. PURIC, Dan, Cine suntem?, București, Edit. Platytera, 2008.

13. SfÂntul Augustin, Confesiuni, ediție bilingvă, trad., introd. și note de Eugen Munteanu, București, Edit. Humanitas, 2018.

14. SFÂNTUl IOAN GURĂ DE AUR, Omilii la Matei, col. „Părinți și Scriitori Bisericești”, vol. 23, trad. Dumitru Fecioru, București, Edit. Institutului Biblic și de Misiune al Bisericii Ortodoxe Române, 1994.

15. SFÂNTUL IOAN GURĂ DE AUR, Omilii la parabola despre săracul Lazăr și bogatul nemilostiv, trad. Adrian Tănăsescu-Vlas, București, Edit. Sophia, 2002. 
16. SfÂNTUL ISAAC SIRUL, Cuvinte despre nevoințăa, Bacău, Edit. Buna Vestire, 1997.

17. StăniloAe, Dumitru, Teologia Dogmatică Ortodoxă, vol. I/III, Bucureşti, Edit. Institutului Biblic și de Misiune al Bisericii Ortodoxe Române, 2010.

18. WARE, Kallistos, Împărăţia lăuntrică, trad. Eugenia Vlad, Bucureşti, Edit. Christiana, 1996. 